\title{
Direct-to-consumer marketing of stem cell interventions by Canadian businesses
}

\author{
Leigh Turner*,1 \\ ${ }^{1}$ Center for Bioethics, School of Public Health, College of Pharmacy, University of Minnesota, N520 Boynton, 410 Church Street \\ SE, Minneapolis, MN 55455, USA \\ *Author for correspondence: Tel.: +1 612626 4830; turne462@umn.edu
}

\begin{abstract}
Aim: This study examines marketing claims of Canadian businesses engaged in direct-to-consumer advertising of putative stem cell treatments. Methods: Internet searches were used to locate Canadian businesses selling stem cell interventions. Company websites were subjected to detailed analysis. Results: In total, 30 Canadian businesses sell stem cell interventions provided at 43 clinics. Autologous stem cells are the most common types of products promoted by such businesses. Company websites minimize risks while making strong claims about benefits of stem cell interventions. Discussion: Businesses' representations could result in patients making health-related decisions informed by marketing claims rather than best available scientific evidence. Conclusion: In the absence of the development of new regulations and guidance, the Canadian direct-to-consumer marketplace for stem cell interventions appears poised for expansion.
\end{abstract}

First draft submitted: 21 March 2018; Accepted for publication: 2 August 2018; Published online: 26 September 2018

Keywords: Canada • clinics • direct-to-consumer marketing • empirical analysis • Health Canada • physicians • stem cells

Over the last decade, health researchers have addressed various ethical, scientific, social and legal issues related to businesses engaged in direct-to-consumer marketing of purported stem cell interventions [1-7]. Early scholarship examining this topic emphasized 'stem cell tourism' to clinics in China, India, Mexico, Panama, Russia, Ukraine and elsewhere by patients from such countries as Australia, Canada and the USA [8-13]. In contrast, recent empirical studies have documented the proliferation of clinics advertising 'stem cell therapies' in such countries as Australia, Japan, Germany, the UK and the USA [14-18]. These new findings undercut the assumption that strict legal standards for premarketing authorization of cell-based therapies and effective regulatory bodies in these latter countries must inevitably drive patients seeking putative stem cell treatments to low and middle income countries with regulatory loopholes or ineffective regulatory agencies $[19,20]$. Businesses marketing stem cell treatments have proliferated in the USA, for example, despite the existence of comprehensive federal regulations related to cells and tissues and the US FDA's reputation as an effective national regulatory body. By 2016, at least 351 US-based businesses and 570 clinics engaged in direct-to-consumer marketing of stem cell interventions $[21,22]$. A follow-up study that extended the search for such companies to May 2017 identified 432 US businesses selling unproven stem cell interventions administered at a total of 716 clinics [23]. Empirical surveys documenting the locations of businesses selling unproven stem cell 'treatments' have also identified 88 clinics in Japan, 70 facilities marketing stem cell interventions in Australia, 16 clinics in the UK and 11 clinics in Germany [24,25]. These findings reveal the extent to which the global marketplace for stem cell interventions has changed since it began attracting scrutiny from researchers.

Despite growing awareness that companies selling purported stem cell treatments are now based in nations where they were not detected a decade ago, some countries with clinics advertising stem cell interventions have thus far attracted little critical scrutiny from researchers. For example, direct-to-consumer marketing of stem cell interventions by companies and clinics based in Canada has to date been the subject of only limited scholarly analysis. A global study of businesses engaged in direct-to-consumer advertising of stem cell interventions found five such companies based in Canada [26]. An examination of Canadian laws and regulations governing the development,

Future Medicine 
testing and commercialization of stem cell therapies noted the existence of 11 such companies, though without describing their marketing claims or otherwise analyzing their business operations and clinical activities [27]. A recent empirical study of Canadian physicians involved in marketing and administering unproven and unapproved stem cell interventions found 15 websites promoting such procedures [28]. Canadian journalists have also reported that stem cell clinics are now operating in Canada [29-33]. Acknowledging the value of these prior analyses, this study contributes to scholarship by providing a detailed empirical analysis of contemporary Canadian businesses engaged in online direct-to-consumer marketing of purported stem cell treatments.

Excluding businesses selling stem cell-based biologics authorized or provisionally authorized for sale by Health Canada and facilities offering hematopoietic stem cell transplants falling within the current standard of medical care for diseases such as acute leukemia and multiple myeloma, this study examines companies and clinics that are based in Canada and market stem cell products that have not been approved by Health Canada, are not routinely provided as current standard of medical care, and that lack conclusive evidence of safety and efficacy generated in the context of controlled clinical trials.

Acknowledging the many important ethical, scientific and regulatory issues associated with direct-to-consumer marketing of unlicensed stem cell interventions, this study does not address in detail moral and legal issues examined elsewhere [34-42]. Rather, this study provides an empirical analysis of Canadian businesses engaged in online direct-to-consumer marketing of purported stem cell treatments for a variety of clinical indications. It does not make any claims about whether particular businesses are complying with all applicable federal and provincial regulations. It also does not address whether healthcare providers performing clinical procedures at such companies and clinics are complying with all applicable standards of federal and provincial legislation and professional codes of ethics. Health Canada and other regulatory agencies are legally empowered to address the former set of questions concerning whether specific businesses are operating in compliance with applicable federal regulations [43,44]. Similarly, provincial Colleges of Physicians and Surgeons and counterpart colleges tasked with overseeing other regulated healthcare practitioners are responsible for investigating cases where there are questions concerning whether clinicians are meeting legal, ethical and professional standards [45]. Though this study does not provide a normative analysis or legal assessment of the specific companies and clinics it describes, patients and their advocates, policy makers and regulators, healthcare ethicists, legal scholars, stem cell researchers, journalists and other parties should all benefit from a detailed empirical examination of Canadian businesses and clinics engaged in online direct-to-consumer marketing of putative stem cell interventions. Furthermore, empirical study of this marketplace can inform ethical, legal and scientific assessments of these businesses' marketing claims, commercial practices and clinical activities.

\section{Methods}

\section{Internet searches}

Using over 40 different search terms and two different internet browsers, Safari and Google Chrome, repeated searches on three search engines, Google, Bing and Yahoo, were used to identify Canadian businesses engaged in online direct-to-consumer marketing of putative stem cell treatments. Searches were conducted using English and French search phrases, utilizing both Canadian and US versions of the three search engines. Representative examples of search terms include 'Canadian stem cell clinics', 'cliniques de cellules souches au Canada', 'stem cell treatments in Canada', 'traitements de cellules souches au Canada', 'stem cell therapy in Canada' and 'la thérapie cellulaire à base de cellules souches au Canada.' Analysis was restricted to Canadian businesses using the internet to advertise directly to prospective clients purported stem cell interventions that are not approved by Health Canada and at present are not widely administered as routine medical interventions falling within the current scope of evidence-based medical care.

All returned links for a minimum 15 pages per search term were reviewed during the process of finding Canadian businesses selling purported stem cell treatments. Searches concluded at 15 pages when no new leads continued to be identified. Searches proceeded to the 20th page if promising leads emerged later in search.

\section{Inclusion \& exclusion criteria}

Company websites were subjected to detailed content analysis if they engaged in online direct-to-consumer marketing of putative stem cell treatments provided at clinical sites in Canada. Companies engaged in such activity but located outside Canada and with clinical sites based outside Canada were excluded from analysis. Similarly, businesses based in Canada were not included in the dataset and subjected to detailed content analysis if they 
marketed unapproved stem cell interventions but referred their clients to international medical facilities. Several identified companies fell into this category. Their business operations are noted in this article, but these companies were not included in the dataset because the stem cell procedures they market are provided outside Canada. International companies that solicit Canadians seeking purported stem cell treatments for various indications were likewise excluded from analysis. Excluded from analysis were organizations selling cell-based biologics authorized or provisionally authorized for marketing by Health Canada. Likewise, healthcare facilities providing access to stem cell interventions widely recognized as current standard of care for particular diseases, such as hematopoietic stem cell transplantation for leukemia, multiple myeloma and lymphoma, were excluded from analysis. Healthcare institutions conducting Health Canada-reviewed and Research Ethics Board-approved investigational studies involving stem cell transplantation were excluded from analysis. Other businesses excluded from analysis were companies marketing storage or banking of stem cells and other human cells and tissues, businesses promoting 'stem cell cosmeceuticals' or 'stem cell nutritional supplements' and firms selling point-of-care cell processing medical devices. Finally, excluded from analysis were companies and clinics selling 'regenerative medicine' products or 'regenerative injection therapies' that did not make explicit reference to the administration of stem cells. For example, Canadian companies that market platelet-rich plasma (PRP) treatments, but do not frame such interventions as 'stem cell therapies' and do not market 'stem cell treatments' independently of PRP procedures were excluded from analysis.

\section{Analysis of company websites}

The inclusion and exclusion criteria were used to create well-defined standards for the identification of businesses and clinics in Canada that engage in online marketing of stem cell interventions. After companies were located and it was determined that they fit inclusion criteria, their websites were analyzed to determine the number of clinical sites as well as the provinces and cities or towns in which clinics were located. Websites were also analyzed to establish whether information was provided about the cost of stem cell procedures and whether payments were provided by patients or third party sources such as public or private health insurers. Website analysis also examined types of stem cells advertised, diseases and injuries reportedly treated with stem cells, details concerning any identified risks and possible complications associated with advertised stem cell interventions, and statements asserting benefits associated with undergoing stem cell procedures. Next, analysis of company websites included recording and examining claims concerning provision of long-term patient follow-up care. Finally, company websites were analyzed to determine whether businesses used various marketing techniques to justify advertised stem cell interventions. Information was gathered from business websites as companies were identified and then entered into a database. Data were subsequently reviewed and updated after the process of searching for businesses had concluded and all identified companies were included in the dataset. Systematic searches commenced in May 2017 and were conducted on a periodic basis until June 2018. The preliminary analysis of business websites also began in May 2017. Final analysis of company websites was conducted in June 2018. Additional information concerning how company websites were analyzed is provided in the Supplementary Codebook.

The search methods for this study were informed by prior empirical studies of companies engaged in online direct-to-consumer marketing of unproven stem cell interventions. However, researchers working in this area have used a variety of search terms and search methods. As a result, findings across studies might not be strictly comparable, and can in part be a result of particular inclusion and exclusion criteria, online search strategies, choice of particular search engines and other factors. The time at which searches are conducted also matters, as the direct-to-consumer marketplace for purported stem cell treatments is dynamic.

\section{Results}

Number of Canadian businesses marketing stem cell interventions \& their clinics

Repeated searches resulted in the identification of 30 Canadian companies engaged in direct-to-consumer online marketing of stem cell treatments. Some companies reported providing stem cell interventions at more than one clinic. In total, the 30 identified businesses operate 43 distinct clinics. Figure 1 provides a geographical representation of where these clinics are located.

In total, 22 businesses administer stem cell interventions at a single clinical site, four companies operate two clinics each, three businesses each operate three clinics and one business has four clinics. Several Canadian companies marketing stem cell interventions refer their clients to healthcare facilities that appear to be located outside Canada. These companies were not included in the tally of 30 companies and 43 clinics. 


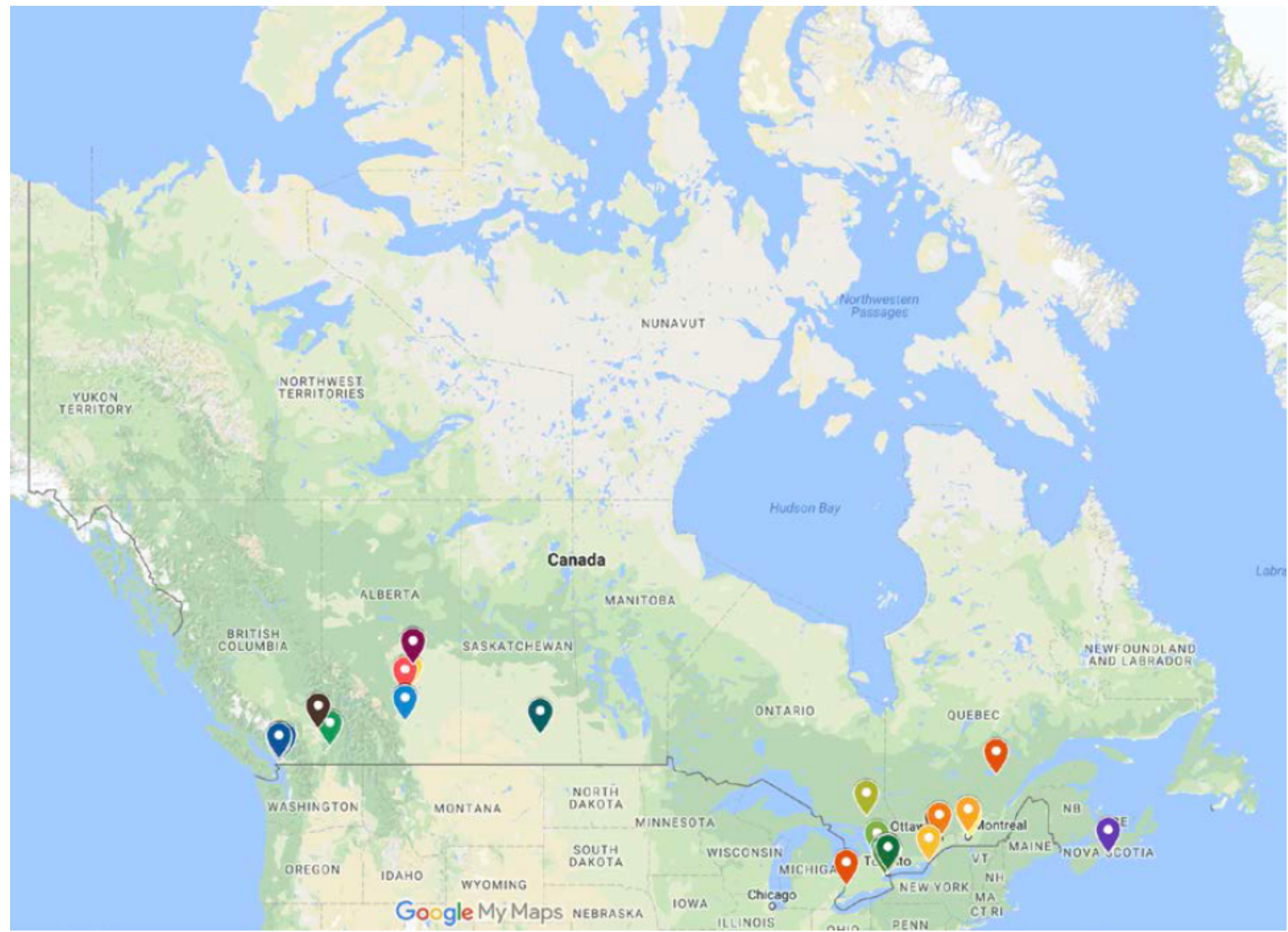

Figure 1. Map featuring Canadian clinics selling stem cell interventions. Map created using Google My Maps.

\section{Geographical distribution of Canadian clinics marketing stem cell interventions}

Canadian clinics providing access to stem cell interventions marketed directly to consumers are located in six provinces. Ontario has 24 such clinics, British Columbia has eight clinics, Alberta has six, Quebec has three, Nova Scotia has one clinic and Saskatchewan also has a single clinic. Searches did not identify businesses and clinics selling stem cell treatments in Canada's other provinces and territories. In general, businesses selling stem cell interventions cluster in or near Canada's larger cities, presumably situated near their intended target markets. For example, 12 clinics are based in Toronto, Canada's largest city by population and five additional clinics are located in the Greater Toronto Area. Figure 2 provides a visual representation of the number of clinics in each province that engage in direct-to-consumer marketing of stem cell interventions. The figure includes only provinces with clinics advertising stem cell interventions.

\section{Cost of advertised stem cell procedures}

In total, 27 businesses do not disclose their fees for advertised stem cell interventions. Some companies urge prospective clients to call if they wish to receive information about cost of stem cell procedures. In contrast, three companies provide some information concerning the cost of stem cell interventions. One business states, "Stem Cell (first site): \$2000 Stem Cell, Each additional Site: \$100; Initial Assessment \$300.” Two other businesses, even though they appear to operate as distinct companies, use identical text when describing fees for stem cell procedures. Websites for these businesses state, "Our current pricing for most adipose-derived stem cell injections, which includes the combination PRP injection, is $\$ 3500$ CAD per injection site; with discounts given for multiple injection sites." At 


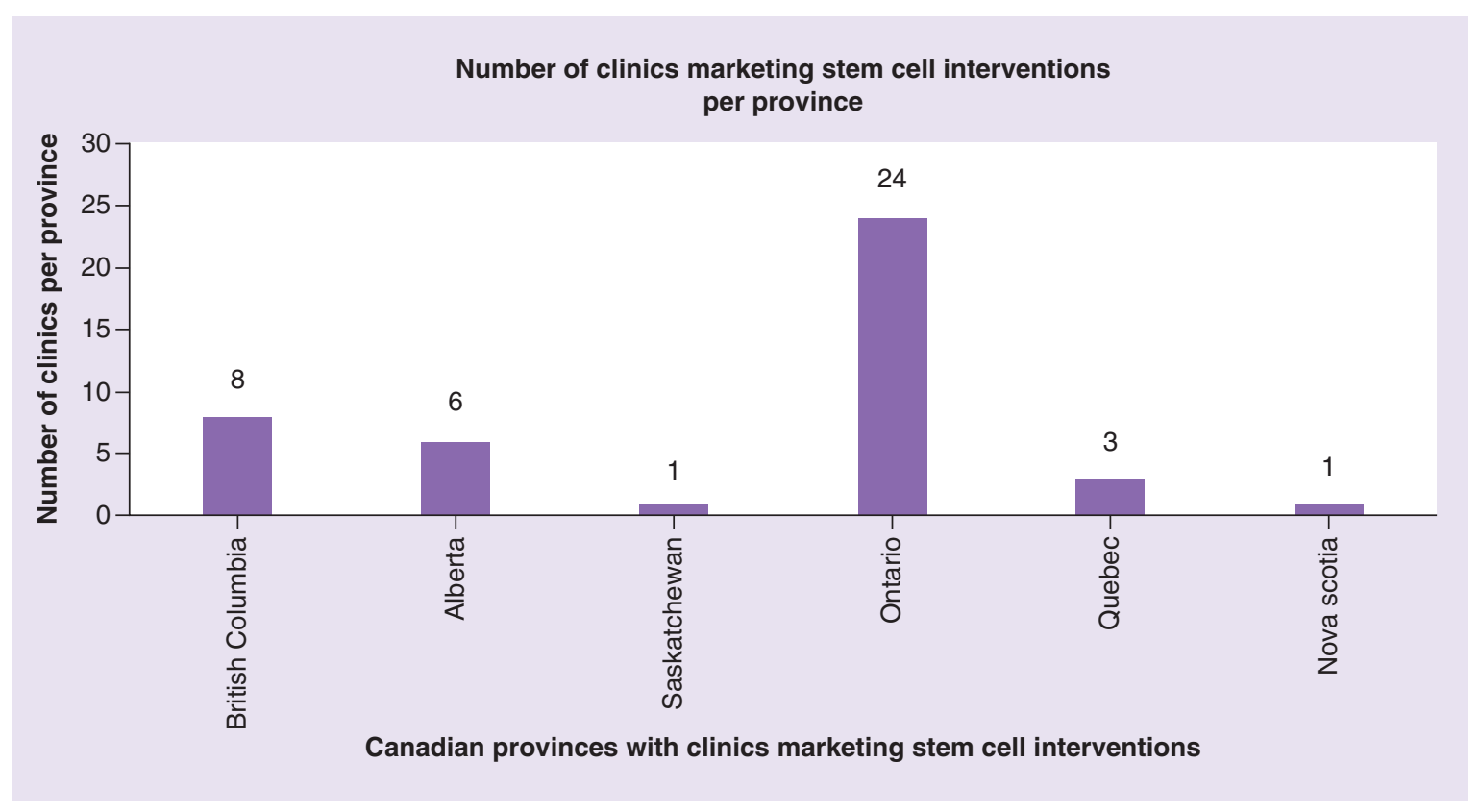

Figure 2. Number of stem cell clinics per province.

these businesses, there appears to be a standard base price for stem cell procedures, with additional fees added if stem cells are injected at more than one anatomical site.

\section{Information concerning who pays for stem cell interventions}

In general, company websites do not provide detailed information concerning who will pay for stem cell procedures. In most cases, because provincial health insurance plans and private health insurers do not provide coverage for such purported treatments, these interventions are purchased by patients as personal out-of-pocket expenses. Highlighting that clients must typically pay for advertised stem cell procedures, one company website states, "Regenerative treatments performed at our clinics are not covered by provincial healthcare and the cost of the procedure is paid for by the patient undergoing treatment." Another website states, "Physician consultations are covered by OHIP. During the consultation, you will discuss if you are a good candidate for injections. The costs of the injections are not currently covered by benefit plans." In total, 21 company websites provided no information concerning payers. Seven company websites explicitly stated that patients are responsible for paying all fees associated with stem cell procedures. One company website mentioned the possibility of applying auto injury insurance or worker's injury insurance on a case by case basis. According to the website, "Please note that Regenerative medicine is not covered by most insurance companies, including Ontario Health Insurance Plan (OHIP). However, on a case-by-case basis, it may be covered by auto injury insurance (MVA) or worker's injury insurance (WSIB)." The frequency with which automobile injury insurers or worker's injury insurance plans accept claims related to stem cell interventions is unclear. One company website encouraged clients to check their workplace extended healthcare plan. Finally, two companies provided information about obtaining financing to cover the cost of advertised stem cell procedures. One of the two companies also noted that the cost of the stem cell interventions it markets might be eligible as a tax-deductible expense. Company websites did not provide additional information about costs and payments. For example, business websites did not specify how many stem cell interventions most clients have and the total average cost of these procedures or indicate how many patients individual companies successfully solicit on an annual basis. Businesses presumably have a propriety interest in not disclosing such information on their websites. The Supplementary Database provides additional documentation concerning statements businesses make about who pays for advertised stem cell interventions.

\section{Types of advertised stem cell-based interventions}

Canadian businesses selling stem cell interventions claim that they use one or more of several different sources of autologous adult cells. Of the 30 identified companies, 22 market autologous stem cells derived from adipose 


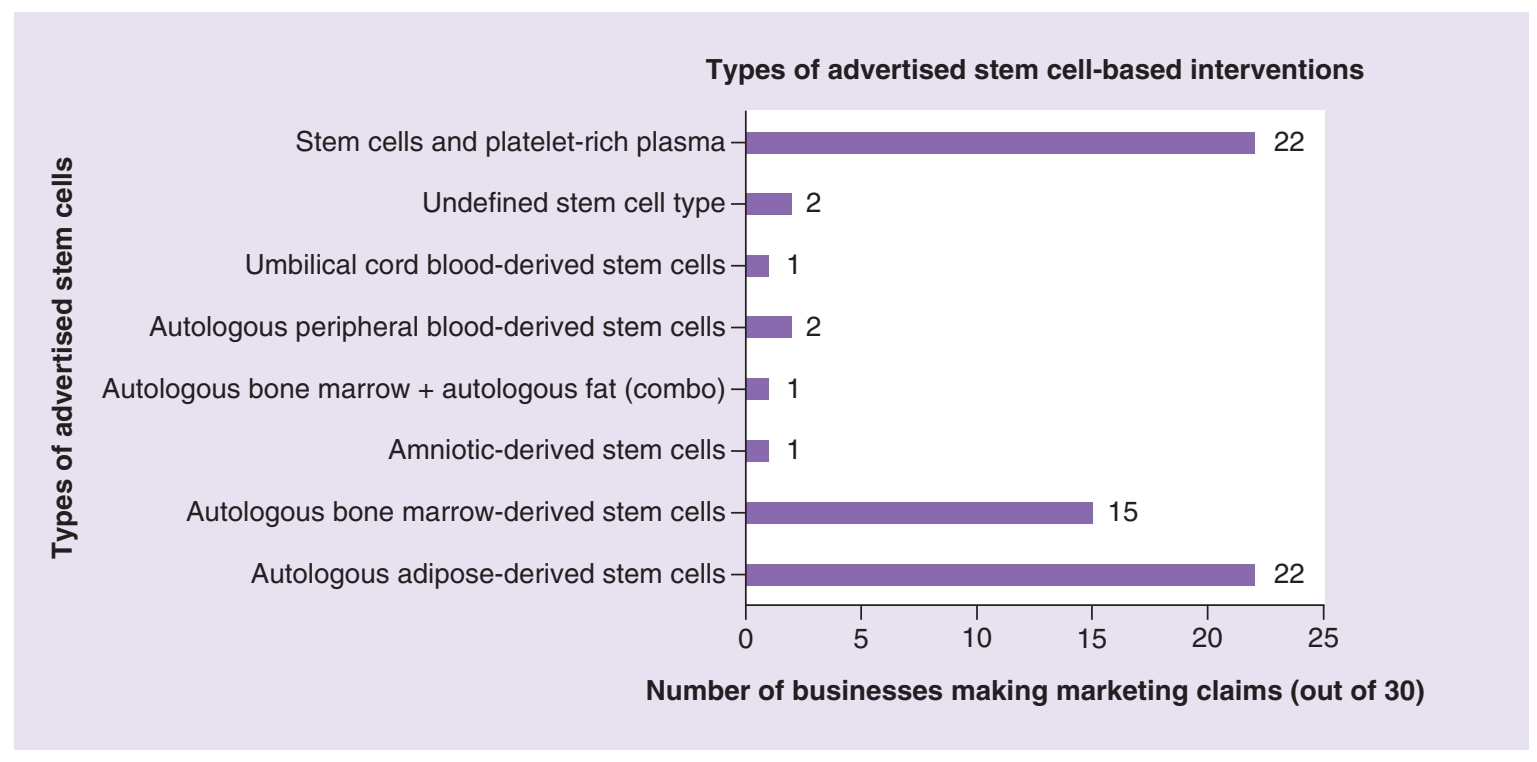

Figure 3. Types of stem cell interventions advertised online by Canadian businesses.

tissue, 15 businesses advertise autologous stem cells obtained from bone marrow and two businesses advertise autologous stem cells reportedly sourced from peripheral blood. Nine companies promote both autologous adipose derived stem cells and autologous stem cells obtained from bone marrow. Two businesses sell undefined stem cell products that are unattributed to any particular source. One company markets amniotic-derived stem cell products in addition to umbilical cord blood-derived stem cell products. A single business advertises autologous bone marrow derived stem cell product combined with autologous adipose-derived stem cells. Most Canadian companies selling stem cell interventions also market PRP 'regenerative injections', administered either alone or in common with stem cell procedures. In total, 22 businesses promoted both stem cell interventions and PRP procedures. Figure 3 summarizes the types of stem cell-based interventions Canadian businesses advertise.

In contrast to the US direct-to-consumer marketplace for stem cell interventions, none of the identified Canadian companies selling purported stem cell treatments advertised allogeneic stem cell products derived from placentas $[46,47]$. Likewise, no Canadian companies made promotional claims about induced pluripotent stem cells, embryonic stem cells, 'very small embryonic-like stem cells' or xenogeneic stem cell products. At present, the range of claims about types of stem cells used by Canadian businesses selling putative stem cell treatments is narrower than the breadth of claims about stem cell types made by their US counterparts.

\section{Stated modes of administering stem cells}

Of the 30 identified businesses, 28 reportedly administer stem cells via injections. Three of these companies also administer stem cells using intravenous (iv.) infusion. One business lists intravenous infusion as its lone mode of administering stem cells. One company does not specify how it administers stem cells to its clients. There were no online claims about other modes of delivering stem cells to patients.

\section{Advertised stem cell interventions}

Of the 30 businesses advertising stem cell interventions, 26 companies market stem cell treatments for orthopedic and musculoskeletal indications such as osteoarthritis, fractures, ligament injuries, tendon injuries and cartilage damage. In total, 23 businesses advertise stem cell procedures for pain relief and 14 promote them for sports-related injuries such as tennis or golf elbow, rotator cuff tears and pitcher's elbow. Six businesses sell stem cell procedures for cosmetic indications such as 'wrinkles and face/neck sagging, skin imperfections and aging of the hands and prominent veins'. Four companies also market stem cells for treatment of hair loss. Three companies advertise stem cell interventions for neurological indications. Two businesses market stem cell interventions for lung diseases, immunological diseases and sex-related indications. Stem cell treatments for aging, muscular dystrophy, cardiac disease and urological diseases are each promoted by one company. 


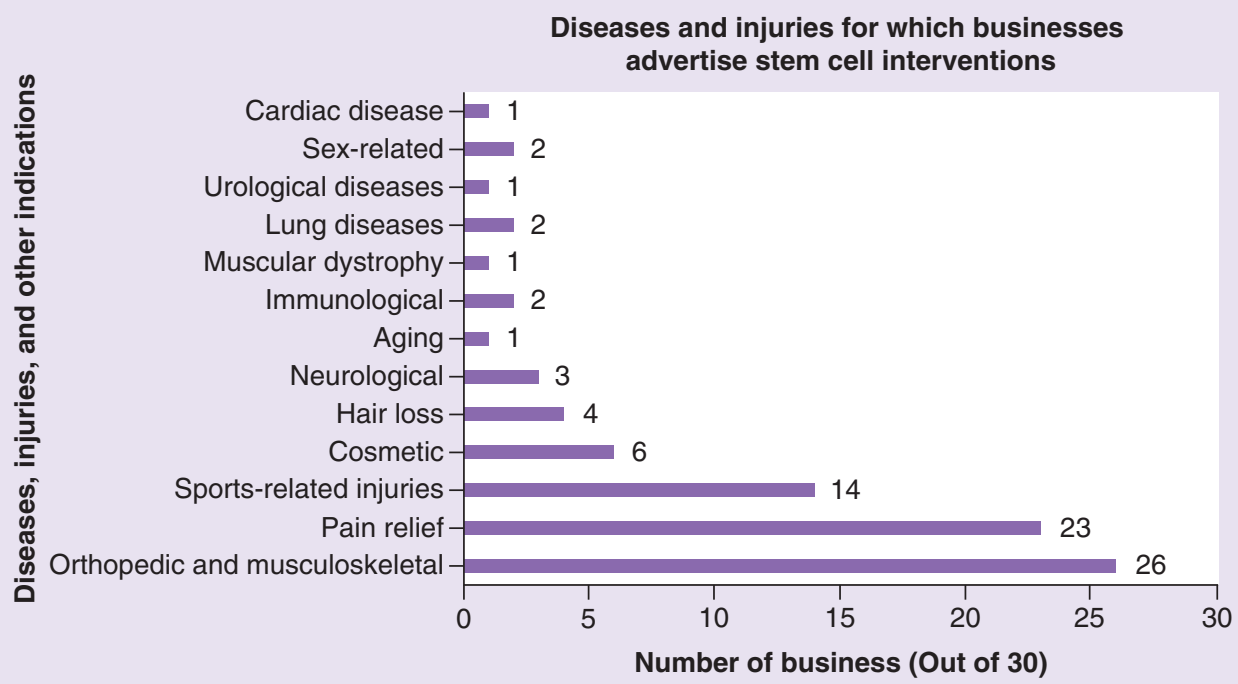

Figure 4. Advertised stem cell interventions.

Most businesses confine their advertising to selling stem cell interventions for orthopedic diseases and injuries, pain management and treatment of sports injuries. However, two companies are conspicuous exceptions to this general trend. One British Columbia-based business advertises autologous adipose-derived stem cell treatments for amyotrophic lateral sclerosis, Parkinson's disease, stroke, multiple sclerosis, scleroderma, auto-immune neuropathy, muscular dystrophy, Crohn's disease, asthma, lung disease, congestive heart failure and cardiomyopathy, postmyocardial infarction, interstitial cystitis, erectile dysfunction, male incontinence and other diseases and injuries. In addition, a medical spa in Ontario markets stem cell interventions for asthma, autism, multiple sclerosis, chronic obstructive pulmonary disease, diabetes, erectile dysfunction and gout, in addition to also marketing stem cells as treatments for orthopedic indications, sports injuries and pain relief. Though numerous Canadian companies market stem cell interventions for orthopedic indications and pain relief, these two companies resemble the many US businesses marketing stem cell 'treatments' for a wide range of diseases and injuries with strikingly different etiologies [48]. Figure 4 summarizes the diseases and injuries for which stem cell interventions are marketed as treatments.

\section{Statements concerning risks \& complications related to advertised stem cell interventions}

Websites for 16 of 30 businesses provided no information concerning risks prospective clients should consider before deciding whether to undergo advertised stem cell interventions. Three of the 16 websites stated there were no risks to disclose. According to one company website, "Unlike botox or fillers injection which is toxic and temporary, autologous cellular treatment is safe with no risk of rejection or scarring." Another site claimed, "Our procedure is very safe and completed in a single visit to our clinic." A third site stated, "The great advantage of autologous stem cells is that the cells and the body are compatible and no rejection occurs against the host."

The remaining 14 company websites contained some information about risks associated with undergoing autologous stem cell interventions. Statements concerning risks typically were restricted to possibility of short-term discomfort and complications after receiving injections or intravenous infusions. For example, one website stated, "Initially the procedure may cause some localized soreness and discomfort... Although uncommon, the potential side effects that may be experienced after undergoing BMAC treatment may include: swelling, pain, joint stiffness, no relief of symptoms, infection and/or allergic reaction." A second website claimed, "The technique is safe and there are no side effects other than the discomfort associated to the inflammatory period sometimes present in the first days following the injection." Such statements are representative of general pattern of companies making assertions about immediate effects of injections when providing information about risks related to advertised stem cell interventions.

Of the 14 business websites mentioning risks associated with stem cell procedures, just two sites disclosed the possibility of serious risks. One of these two sites claimed, "The risks of these procedures include but are not limited 

advertised stem cell interventions.

Examples of identified risks related to stem cell interventions:

'Some local discomfort and bruising at both the fat harvesting site and the injection site are normal, lasting up to 1-2 weeks. As with any procedure that penetrates the skin, there is a low risk of infection. Finally, the usual risks of liposuction that result from large amounts of fat being removed do not apply here based on the small quantity being taken. Furthermore, as local anesthetic is used, the risks that accompany general anesthesia and/or iv. sedation do not apply.'

'Side effects are possible, but very unlikely. Regenerative injection therapies are considered conservative approaches to treating pain and injuries, but like any medical procedure where a needle is inserted through the skin, infection can occur. Most patients will also experience mild inflammation and pain at the injection site following the procedure.'

'Post injection soreness at the injection site (the site we are treating) is sometimes present due to the inflammatory response caused by the regenerative therapy. This post procedure soreness generally resolves within a few days after.'

'For most people, there will be some initial swelling and discomfort in the injected area, but this is usually easily managed with basic movement.'

'Are There Any Risks to a Stem Cell Transplant? Some local discomfort and bruising at both the fat harvesting site and the injection site are normal, and can last up to 12 weeks. As with any procedure that penetrates the skin, there is a low risk of infection. The usual risks of liposuction, resulting from large amounts of fat being removed do not apply, based on the small quantity actually being harvested. Furthermore, as local anesthetic is used, the risks that accompany general anaesthesia and/or iv. sedation do not apply.'

'Following stem cell injections for all patients, it is important to avoid anti-inflammatory medications for 1-2 weeks and modify your activities as instructed by your orthopedic surgeon. If you have soreness in the joint or harvest site, you can take acetominophen for symptom relief.'

'Our adult stem cell therapies are safe, simple, and non-invasive, and have the potential to help those who may have exhausted the possibilities of other treatments. Treatments using your own adult stem cells have been shown to restore some normal functions that had been written off as gone forever.'

'The side effects of the adipose tissue lipo-aspirate procedure are minimal and may include: minor swelling, bruising and redness at the procedure site and/or tenderness at the procedure site. These side effects typically resolve after 4-5 days. Occasionally, some patients will have sensitivity to the lidocaine and may experience headache or nausea. No long-term negative side effects or risks have been reported. The side effects of the ADSC injection itself are also minimal and may include: localized joint pain and swelling, difficulty walking or limited range of motion. However, these side effects typically resolve after a few days and no long-term negative side effects or risks have been reported. It is important to note that anytime the skin is broken during a medical procedure, there is a risk of bleeding or infection but this occurs less than $1 \%$ of the time.'

to pain (likely over 50\%), fainting or lightheadedness (less common, 5-10\%), bleeding and bruising (rare, less than 1\%), infection (very rare, less than 1/50,000), allergic reaction to lidocaine (extremely rare) and possible loss of life or limb (exceedingly rare). Although these possibilities exist, the chance of them happening is generally less than with a standard surgical operation." A second site stated, "There could be pain or substantial risks involved. These concerns should be discussed with your healthcare provider before any treatment so that you are properly informed and understand that there are no guarantees to healing." However, that same company website also stated, "Stem cell therapy is safe, and a procedure can be completed within just a few hours. Stem cell therapy makes it possible to avoid the complications associated with surgical procedures. Stem cell treatments are minimally invasive, with low risks and a short recovery time." It is unclear how prospective patients interpret such conflicting marketing claims.

Box 1 and the Supplementary Database provide additional examples of statements businesses marketing stem cell interventions make about procedure-related risks. References to risk are dominated by statements about minor risk, pain or discomfort associated with injections or infusions of stem cells rather than more serious risks and complications that might occur, whether immediately after cells are administered or at a later date, as a result of patients undergoing stem cell procedures.

In general, company websites did not describe in detail risks prospective clients should consider before deciding whether to have stem cell procedures. Acknowledging lack of meaningful risk-related information on company websites, patient-physician conversations and informed consent processes before procedures would presumably provide additional opportunities for healthcare providers to provide patients with additional information about risks, benefits and alternatives to stem cell interventions. To date, researchers have not addressed what employees 
Box 2. Examples of reported benefits associated with stem cell interventions.

'These stem cell injections show promise for treating avariety of sports injuries. Our research tells us bone injuries are at the top of that list. We can treat athletes that have suffered a fracture as a result of a collision or accident on the court or rink.'

'Stem cell injections are a regenerative cell-based therapythat can be used for the management of inflammatory conditions such as tendonitis, joint pain associated with early arthritis and cartilage damage. These injections have been shown to help treat conditions that were unresponsive to alternate therapies such as platelet rich plasma (PRP) injections or Durolane. There is evidence that the benefits may include dramatic anti-inflammatory effects and the potential to aid tissue repair.'

'Unlike treatments that mask the symptoms of tissue damage, bone marrow aspirate concentrate (BMAC) therapy can actually help heal damaged tissue to alleviate pain, reduce or eliminate the need for traditional treatments like medicine or surgery, and dramatically increase the patient's function... BMAC therapy is a cutting-edge regenerative treatment. It uses the patient's own stem cells, which aid in tissue regeneration and bone formation, to accelerate healing in moderate to severe osteoarthritis and/or tendon injuries. The number of regenerative cells that respond to injury is often inadequate. BMAC therapy provides stem cells to injured tissue to fuel the body's natural healing mechanism.'

'This exciting therapy utilizes a patient's adipose (fat)derived stem cells (ADSC) combined with PRP to provide a potent biological therapeutic combination... ADSC provide a living bio-scaffold and a multi-potent cell replenishment source (i.e,. capable of differentiating into many different cell types) useful for healing musculoskeletal disorders. These stem cells are capable of differentiating into bone, cartilage, tendon, ligament, and muscle. Combined with platelet rich plasma, which contains growth factors and cytokines that stimulate the stem cells, the management of various musculoskeletal disorders, including osteoarthritis and chronic soft tissue tears/degeneration, has taken a big step forward.'

'Many patients have experienced a high success rate with ourprocedures after traditional treatments like physical therapy, rest, and surgery have failed. Results of our stem cell therapy include accelerated healing, and for many patients, pain relief that can last for years and, in some soft tissue injuries, permanently.'

'Stem cells can become any kind of new tissue to healinjuries... Utilizing ultrasound guidance, the stem cells along with peripherally drawn platelet rich plasma are injected into the joint, tendon, or tissue. The stem cells are then able to recognize and transform into the surrounding cell types thereby regenerating tissue.'

'We offer advanced regenerative medicine and treatments thatboost the body's ability to heal naturally in order to renew, repair, and restore worn joints and ligaments, alleviate osteoarthritis, and heal sports injuries. We currently utilize PRP and Adipose-derived Stem Cells (ADSC) - a source of mesenchymal stem cells - as our orthobiologic therapies.'

- whether clinicians or marketing representatives - of Canadian businesses selling stem cell interventions say to clients during such exchanges or what information about risks is provided during processes of seeking informed consent from patients before procedures occur. Furthermore, researchers have yet to investigate how clients of such businesses interpret whatever information is provided to them and incorporate details about risks and benefits into their decision making. Whatever risk-related information is conveyed in such patient-physician interactions, little meaningful data about risks are disclosed to prospective clients when they engage in information-gathering by visiting company websites. Given the reports of patients harmed as a result of undergoing unproven and unlicensed stem cell interventions, limited disclosure of possible complications is cause for serious concern [49-52].

\section{Statements concerning benefits reportedly related to advertised stem cell interventions}

Websites of all 30 Canadian businesses advertising stem cell interventions included assertions concerning the effectiveness of such procedures. Companies did not use the rhetoric of definitively curing particular diseases and injuries. Rather, businesses made claims concerning therapeutic promise and general effectiveness of stem cell therapies and indicated possibility or likelihood of benefit. For example, one company website stated, "What are the potential benefits of these injections? Improve symptoms, regain function after injury, Eliminate the need for more aggressive treatments such as long-term medication or surgery." A second website stated, "The main benefits of stem cell therapy are: significant and long-term pain relief, Increase in function and range of motion." A third company claimed, "The benefit of the injections often takes a few weeks, but to date, our patients are experiencing a very positive effect with stem cell treatments." Another business stated, "If you're suffering from an injury or chronic condition that causes pain, let us help promote healing with regenerative injections. Our injection therapy techniques have helped countless patients." Box 2 and the Supplementary Database provide additional examples of statements Canadian businesses have made concerning benefits associated with their advertised stem cell procedures. 
Most businesses make positive but imprecise, unquantified claims about the therapeutic promise of the stem cell interventions they promote. However, five companies make quantitative claims about the frequency with which their clients reportedly experience clinical benefits. For example, one company's website states, "Weve found our average patient notices $76 \%$ pain relief after the procedure. Roughly $80 \%$ of the stem cell procedures we perform are successful... We consider a procedure successful if a patient experiences at least a 50\% reduction in pain/symptoms." Another company claims, "Despite the best efforts of physicians, researchers and other health professionals, nothing in medicine is ever guaranteed. However, clinical research and anecdotal accounts have been very promising, with as high as 80-90\% of patients experiencing positive results, decreased pain and improved function." A third company website states, "WHAT PERCENTAGE IS EFFECTIVE? 85\%." The five businesses making quantitative statements about efficacy do not provide links to peer-reviewed publications, unpublished data or other sources of evidence for their claims. It is therefore impossible to know whether meaningful data support such assertions. How prospective clients interpret and evaluate such quantitative claims is also unclear. Positive statements about efficacy appear to serve as one of the many techniques companies use to help market stem cell interventions.

\section{Statements concerning long-term patient follow-up care}

None of the 30 companies engaged in direct-to-consumer marketing of stem cell interventions provided information concerning provision of long-term patient follow-up care. Two businesses made reference to short-term postprocedure visits. One company indicated that it scheduled initial follow-up appointments at 4-6 weeks post-stem cell procedure, with second follow-up appointments scheduled 4-6 weeks after the initial follow-up visits. Another business mentioned providing follow-up appointments at 1-2 weeks or 3-6 months. No companies indicated providing long-term patient follow-up care 6 months or more after stem cell procedures.

\section{Using tokens of scientific legitimacy to market stem cell interventions}

A recent critique of businesses marketing unproven stem cell-based interventions identified various 'tokens of scientific legitimacy' such companies use to justify marketing putative stem cell treatments [53]. The list of tools or techniques used to create the impression of scientific legitimacy included companies:

- Claiming they had been accredited, received awards or had their products or practices certified;

- Establishing and emphasizing in their marketing scientific or medical advisory boards composed of eminent individuals and scientists;

- Claiming they were administering stem cell interventions that had been subjected to ethics review;

- Locating themselves in labs or other spaces situated within credible or scientific or government organizations;

- Asserting they or affiliated clinicians were members of established, reputable academic or professional societies;

- Claiming to maintain outcome registries and monitor patients' clinical outcomes;

- Claiming to possess patent applications demonstrating the novelty and usefulness of their advertised stem cell interventions;

- Publishing articles in journals with questionable quality of peer review to create the impression of participating in cutting edge stem cell research;

- Claiming they were justified in administering stem cell interventions to humans on basis of published preclinical and clinical findings by scientists at other institutions;

- Creating organizations intended to help justify commercialization of stem cell interventions by suggesting that the direct-to-consumer stem cell industry is capable of self-regulation;

- Using technical, scientific language to create the appearance of scientific expertise and rigor;

- Using personal testimonials and endorsements to market stem cell interventions.

Such claims reportedly provide prospective clients with assurances that businesses are promoting credible, safe, effective and evidence-based stem cell treatments.

Websites of Canadian businesses marketing stem cell interventions were examined to address whether such companies use various 'tokens of scientific legitimacy'. Of 30 businesses, 27 used technical, scientific language in their advertising. The analysis did not attempt to make company-by-company granular distinctions between accurate and inaccurate uses of such scientific terminology. In total, 14 company websites made assertions about affiliated clinicians' memberships in academic or professional societies. Ten companies referred to preclinical or clinical studies to justify marketing and administering stem cells to humans. Six companies used testimonials by patients as a marketing technique. Two company websites referred to accreditation and awards. One clinician 
appeared to administer stem cells within an academic institution. A single business claimed its stem cells were administered within the context of a study that had been reviewed and approved by an institutional review board (the US equivalent of what in Canada is typically referred to as a research ethics board). The same company also claimed to contribute outcomes data to a clinical registry and be part of a larger organization that had published findings in a peer-reviewed journal. No company websites referred to boards and advisors, registration of clinical studies in registries and databases such as ClinicalTrials.gov, patents or efforts to engage in industry self-regulation. Acknowledging some variation in the 'tokens of scientific legitimacy' used by Canadian businesses marketing stem cell interventions, the most common marketing techniques emphasize scientific and technical rhetoric to make a persuasive case for using stem cell interventions to treat various clinical indications.

\section{Discussion}

30 Canadian businesses operating 43 clinics engage in direct-to-consumer marketing of putative stem cell products. The clinics are concentrated in six provinces, with more than half of them based in Ontario. Although some businesses provide access to stem cell interventions administered at several clinics, to date Canada has not, in contrast to the USA, yet witnessed the emergence of national franchises of businesses composed of dozens of affiliated or networked 'stem cell clinics'.

Patients typically pay out of pocket for advertised stem cell interventions, though some businesses indicate the possibility that on a case-by-case basis third party payers might cover some stem cell procedures. Most of the businesses market stem cell interventions for orthopedic and musculoskeletal indications or pain relief. Two companies differentiate themselves from the rest of the direct-to-consumer marketplace in Canada by advertising autologous stem cell interventions for a wide range of indications, including neurological, immunological, cardiovascular and respiratory diseases. Companies typically emphasize the safety of advertised stem cell interventions, either indicating that such procedures involve no risks or pose minor and transient risk of pain, discomfort or infection. All of the businesses make assertions about the therapeutic benefits associated with the stem cell interventions they sell. Five companies made precise quantitative assertions about efficacy, though they provided no peer-reviewed data or publications to support these assertions. None of the companies made statements concerning provision of long-term patient follow-up care. Numerous tokens of scientific legitimacy are used by businesses, though the most common technique uses scientific and technical rhetoric to justify administration of stem cells for various clinical indications.

Health Canada, Canada’s federal regulatory agency responsible for overseeing premarketing authorization of stem cell-based medical products, does not appear to have taken disciplinary action against any of the 30 businesses currently engaged in online direct-to-consumer marketing of stem cell treatments. If such regulatory action has occurred, a review of Health Canada's website suggests that it is not a matter of public record. Likewise, there do not appear to be any publicly documented reports of provincial colleges of physicians and surgeons or other provincial professional licensing bodies disciplining physicians or other healthcare providers at these companies and clinics for participating in the marketing, sale and administration of stem cell interventions that have not been approved by Health Canada. Health Canada reportedly has requested information from some Canadian businesses advertising stem cell interventions [54]. It is possible that additional investigative actions or regulatory activities on the part of Health Canada or other bodies has occurred outside public purview. It is also conceivable that Health Canada and provincial regulatory authorities are aware of these businesses, have evaluated their marketing claims and clinical practices and determined that they are operating in compliance with all applicable regulatory standards. Acknowledging that federal or provincial regulatory authorities could be taking steps to address the direct-to-consumer stem cell marketplace in Canada, to date Canadian businesses selling stem cell interventions do not appear to have prompted publicly visible regulatory interventions by Canadian regulatory bodies.

At present, Canadian businesses marketing minimally manipulated autologous stem cell products used for homologous purposes are not required by law to obtain premarketing authorization from Health Canada. Which autologous stem cell products fall within the scope of minimal manipulation is not clearly and precisely defined by Canadian federal regulations. Likewise, what constitutes homologous uses of autologous stem cells obtained from adipose tissue, bone marrow and peripheral blood is not clearly specified by Canadian federal regulations. Canadian health researchers have identified this regulatory space as a 'gap' that needs to be better addressed by Health Canada [55].

Absent explicit regulatory standards and guidance addressing the legal status of autologous stem cell products, and in the absence of meaningful enforcement activity by federal and provincial regulatory authorities, it seems 
likely that the Canadian direct-to-consumer marketplace, much like the US marketplace, will expand, with a growing number of companies and clinics making range of claims about the manner stem cell interventions can be used for variety of indications. Assuming current trends persist, these businesses will claim to provide patients with therapeutic options. Some Canadians will presumably prefer having the opportunity to undergo stem cell procedures in Canada rather than having to travel to clinics in the USA, Mexico, China, India or elsewhere. However, despite the appearance of increased consumer choice, in numerous cases, Canadian businesses are selling stem cell interventions for which conclusive evidence of safety and efficacy, obtained in the context of controlled clinical trials, is at present lacking. Furthermore, some companies advertise stem cell procedures in a manner that inadequately discloses risks. Many businesses also make assertions about benefits that do not appear to be supported by peer-reviewed evidence of efficacy demonstrated in context of randomized controlled trials. Patients' ability to make informed choices risks being undermined if they are not provided with accurate, evidence-based accounts of risks and benefits related to advertised stem cell interventions and evidence-based alternatives to proposed stem cell procedures. Also of concern, Canadian companies marketing stem cell interventions provide no information about offering long-term patient follow-up care. Just one company claims it enters its patients' outcomes data in clinical registry, and this information does not appear to be publicly accessible and available for critical scrutiny.

In the USA, the proliferation of businesses selling unlicensed and unproven stem cell interventions has resulted in a growing number of patients who have been seriously harmed by stem cell procedures that they believed would help them [56-62]. Other patients allege they were defrauded by companies making false marketing claims [63,64]. Whether some of the harms that have occurred as a result of an inadequately regulated marketplace for the direct-to-consumer advertising of stem cell interventions in the USA will also occur in Canada remains to be determined.

Better regulatory guidance and more active and engaged oversight by federal and provincial authorities will help ensure that patients obtain access to safe, efficacious, evidence-based stem cell interventions. It will also help protect individuals from spending thousands of dollars to purchase purported stem cell products that in some cases could be unsafe, ineffective or both risky and unlikely to produce therapeutic benefits. Ensuring that businesses make accurate, evidence-based claims about safety, efficacy and regulatory status of the stem cell products they advertise would represent a starting point for better oversight of this expanding marketplace. In addition, regulatory authorities need to ensure that healthcare practitioners administering putative stem cell treatments are qualified to deliver such interventions and provide them in an ethical and professional manner that complies with the current standard of care.

\section{Conclusion}

In the absence of detailed federal and provincial regulations providing precise legal standards applicable to autologous stem cell products and the healthcare providers who market and administer them, a growing number of businesses and clinics in Canada have entered the direct-to-consumer marketplace for stem cell interventions. Acknowledging the promise and potential of stem cell therapies, some of the stem cell interventions available for purchase in the Canadian direct-to-consumer marketplace do not appear to be supported by conclusive evidence of safety and efficacy acquired in the context of properly designed and carefully conducted controlled clinical trials. Rather, companies selling such stem cell products claim that they are not legally required to generate evidence of safety and efficacy and obtain premarketing authorization from Health Canada before marketing and administering putative stem cell treatments.

The lack of safety and efficacy data concerning some of these procedures raises questions about whether some putative 'stem cell therapies' have been prematurely commercialized in Canada, as in other countries where unapproved stem cell products are promoted on a direct-to-consumer basis. Commercialization of cell-based interventions before they are supported by compelling safety and efficacy data could expose individuals to foreseeable, preventable risks and increases the likelihood of harm to patients. Such harms could include physical injuries, substantial financial expenditures with little prospect of improved health and dashed hopes and expectations after stem cell interventions portrayed as being efficacious do not lead to therapeutic benefits. At the level of public goods rather than risks to individual patients, individuals who undergo stem cell interventions provided on direct-toconsumer basis will likely be precluded from participating in clinical trials that might produce more robust clinical data than what businesses selling stem cell treatments are likely to generate, if they in fact gather and publish peer reviewed data [65].

In the USA, the FDA has responded to the proliferation of businesses engaged in direct-to-consumer advertising of stem cell treatments by stating that the agency intends to more effectively enforce federal regulations and better 
oversee this marketplace [66]. To date, Health Canada, provincial colleges of physicians and surgeons, and other Canadian federal and provincial regulatory bodies have not provided clear indication concerning whether they intend to more rigorously oversee Canada's direct-to-consumer stem cell marketplace. Given the emergence of 30 Canadian businesses and 43 clinics already advertising and administering putative stem cell treatments, detailed guidance is needed from Canadian regulatory bodies concerning what stem cell interventions can be directly marketed and provided to prospective clients while practicing medicine within the current medical standard of care and without first obtaining premarketing authorization from Health Canada. In particular, guidance needs to precisely define such concepts as 'minimal manipulation' of cells and tissues and 'homologous use' of autologous stem cell products. Greater clarity concerning what constitutes nonhomologous use of such products and which processing methods result in more than minimal manipulation of particular types of cells and tissues is crucial given that imprecise use of such terms has resulted in the creation of a regulatory exception of uncertain and ill-defined scope. Regulatory guidance should also address when allogeneic stem cell products can be sold without first obtaining premarketing authorization from Health Canada. In the interim, the absence of clear regulatory standards and guidance appears to be serving as de facto public policy that is enabling the proliferation of businesses selling purported stem cell treatments for wide range of clinical indications.

\section{Summary points}

- This study examines claims made by Canadian businesses engaged in direct-to-consumer online marketing of purported stem cell interventions.

- Content analysis of company websites examined location and number of clinical sites, information about costs of stem cell procedures and whether payments are made by patients or third parties, types of stem cells advertised, disease and injuries reportedly treated with stem cells, statements about risks and benefits, assertions about provision of long-term care and claims about various tokens of legitimacy.

- In total, 30 Canadian companies engage in direct-to consumer marketing of stem cell interventions. These interventions are provided at 43 clinics.

- 24 clinics are located in Ontario, eight are in British Columbia, six are in Alberta, three are in Quebec, one is in Saskatchewan and one is in Nova Scotia.

- Most businesses do not disclose what they charge for advertised stem cell procedures. In most cases, stem cell interventions are purchased by patients as personal out-of-pocket expenses. However, some company websites mention possibility of payment by third party sources. Two businesses mention private financing options.

- 22 businesses market autologous stem cells derived from adipose tissue, 15 businesses advertise autologous bone marrow derived stem cells and two companies promote autologous stem cells reportedly obtained from peripheral blood. Two businesses sell undefined stem cell products and one company markets amniotic-derived stem cell products.

- 28 businesses administer stem cells via injections, one company lists intravenous infusion as its lone mode of administering stem cells and one company does not indicate how it administers stem cells to patients.

- 26 companies market stem cell treatments for orthopedic and musculoskeletal indications, 23 businesses advertise stem cells for pain relief and 14 promote them for sports-related injuries. Six businesses sell stem cell procedures for cosmetic indications. Three companies market stem cell interventions for neurological indications and two market stem cells for lung diseases, immunological diseases and sex-related indications.

- 16 out of 30 businesses provided no information concerning procedure-related risks. In total, 14 company websites provided some information about risks associated with stem cell interventions. However, statements concerning risks typically were related to possibility of short-term discomfort. Just two businesses mentioned possibility of serious risks. All 30 businesses advertising stem cell interventions made claims about benefits associated with such procedures.

- No companies provided information concerning provision of long-term follow-up care.

- Companies used various tokens of scientific legitimacy to advertise stem cell interventions. In total, 27 used technical scientific language in their marketing, 14 companies referred to clinicians' membership in academic or professional societies, ten companies referred to preclinical or clinical studies, six companies used testimonials and two companies referred to accreditation and awards.

- Absent explicit regulatory standards and guidance documents addressing the legal status of autologous stem cell products, and absent more robust enforcement by federal and provincial regulatory authorities, the Canadian direct-to-consumer marketplace for stem cell interventions appears poised to expand. This marketplace poses various risks to patients considering undergoing stem cell interventions. 
Supplementary data

To view the supplementary data that accompany this paper please visit the journal website at: www.futuremedicine.com/doi/full/ 10.2217/rme-2018-0033

\section{Acknowledgements}

The author wishes to thank the three anonymous reviewers of an earlier version of this paper for their feedback.

\section{Disclaimer}

The opinions expressed in this article are those of the author and do not necessarily reflect the views of Future Medicine Ltd.

\section{Financial \& competing interests disclosure}

The author has no relevant affiliations or financial involvement with any organization or entity with a financial interest in or financial conflict with the subject matter or materials discussed in the manuscript. This includes employment, consultancies, honoraria, stock ownership or options, expert testimony, grants or patents received or pending, or royalties.

No writing assistance was utilized in the production of this manuscript.

\section{Open access}

This work is licensed under the Attribution-NonCommercial-NoDerivatives 4.0 Unported License. To view a copy of this license, visit http://creativecommons.org/licenses/by-nc-nd/4.0/

\section{References}

Papers of special note have been highlighted as: • of interest; $\bullet \bullet$ of considerable interest

1. Sipp D. The unregulated commercialization of stem cell treatments: a global perspective. Front. Med. 5(4), 348-355 (2011).

2. Cohen CB, Cohen PJ. International stem cell tourism and the need for effective regulation. Part I: stem cell tourism in Russia and India: clinical research, innovative treatment, or unproven hype? Kennedy Inst. Ethics J. 20(1), 27-49 (2010).

3. Cohen CB, Cohen PJ. International stem cell tourism and the need for effective regulation. Part II: developing sound oversight measures and effective patient support. Kennedy Inst. Ethics J. 20(3), 207-230 (2010).

4. Bowman M, Racke M, Kissel J, Imitola J. Responsibilities of Health Care professionals in counseling and educating patients with incurable neurological diseases regarding 'stem cell tourism': caveat emptor. JAMA Neurol. 72(11), 1342-1345 (2015).

5. Drabiak-Syed K. Challenging the FDA's authority to regulate autologous adult stem cells for therapeutic use: Celltex Therapeutics' partnership with RNL Bio, substantial medical risks, and the implications of United States $v$. Regenerative Sciences. Health Matrix Clevel. 23(2), 493-535 (2013).

6. Sipp D, Turner L. US regulation of stem cells as medical products. Science 338(6112), 1296-1297 (2012).

7. Kiatpongsan S, Sipp D. Monitoring and regulating offshore stem cell clinics. Science 323(5921), 1564-1565 (2009).

- Examines the emergence of international clinics marketing stem cell interventions, and notes travel by patients to such facilities.

8. Lau D, Ogbogu U, Taylor B, Stafinski T, Menon D, Caulfield T. Stem cell clinics online: the direct-to-consumer portrayal of stem cell medicine. Cell Stem Cell 3(6), 591-594 (2008).

-• Provides an early empirical analysis of online direct-to-consumer marketing by 'stem cell clinics'.

9. Obgogu U, Rachul C, Caulfield T. Reassessing direct-to-consumer portrayals of unproven stem cell therapies: is it getting better? Regen Med. 8(3), 361-369 (2013).

- Provides a follow-up empirical study of clinics engaged in online marketing of stem cell interventions.

10. Ryan KA, Sanders AN, Wang DD, Levine AD. Tracking the rise of stem cell tourism. Regen. Med. 5(1), 27-33 (2010).

11. Caulfield T, Zarzeczny A, Toronto Stem Cell Working Group. Stem cell tourism and Canadian family physicians. Can. Fam. Physician 58(4), 365-368, (2012)

12. Hyun I. Therapeutic hope, spiritual distress, and the problem of stem cell tourism. Cell Stem Cell 12(5), 505-507 (2013).

13. Sipp D. The unregulated commercialization of stem cell treatments: a global perspective. Front. Med. 5(4), 348-355 (2011).

14. Berger I, Ahmad A, Bansal A, Kapoor T, Sipp D, Rasko JE. Global distribution of businesses marketing stem cell-based interventions. Cell Stem Cell 19(2), 158-162 (2016)

- Offers a detailed empirical survey of the global marketplace of businesses selling purported stem cell interventions.

15. Connolly R, O’Brien T, Flaherty G. Stem cell tourism - a web based analysis of clinical services available to international travellers. Travel Med. Infect. Dis. 12(6 Pt B), 695-701 (2014).

16. Fujita M, Hatta T, Ozeki R, Akabayashi A. The current status of clinics providing private practice cell therapy in Japan. Regen. Med. 11(1), 23-32 (2016). 
17. Munsie M, Lysaght T, Hendl T, Tan HL, Kerridge I, Stewart C. Open for business: a comparative study of websites selling autologous stem cells in Australia and Japan. Regen. Med. 12(7), 777-790 (2017).

-• Examines websites of businesses advertising stem cell interventions in Australia and Japan.

18. Turner L, Knoepfler P. Selling stem cells in the USA: assessing the direct-to-consumer industry. Cell Stem Cell 19(2), 154-157 (2016).

19. Caulfield T, Zarzeczny A, McCormick J et al. The stem cell research environment: a patchwork of patchworks. Stem Cell Rev. 5(2), 82-88 (2009).

20. Caulfield T, Zarzeczny A, McCormick J et al. International stem cell environments: a world of difference. Nat. Rep. Stem Cells (2009).

21. Knoepfler P, Turner L. The FDA and the US direct-to-consumer marketplace for stem cell interventions: a temporal analysis. Regen. Med. 13(1), 19-27 (2018).

22. Turner L, Knoepfler P. Selling stem cells in the USA: assessing the direct-to-consumer industry. Cell Stem Cell 19(2), 154-157 (2016).

23. Turner L. The US direct-to-consumer marketplace for autologous stem cell interventions. Perspect. Biol. Med. 61(1), 7-24 (2018).

24. Berger I, Ahmad A, Bansal A, Kapoor T, Sipp D, Rasko JE. Global distribution of businesses marketing stem cell-based interventions. Cell Stem Cell 19(2), 158-162 (2016).

25. Munsie M, Lysaght T, Hendl T, Tan HL, Kerridge I, Stewart C. Open for business: a comparative study of websites selling autologous stem cells in Australia and Japan. Regen. Med. 12(7), 777-790 (2017).

26. Berger I, Ahmad A, Bansal A, Kapoor T, Sipp D, Rasko JE. Global distribution of businesses marketing stem cell-based interventions. Cell Stem Cell 19(2), 158-162 (2016).

27. Chisholm J, Von Tigerstrom B, Bedford P, Fradette J, Viswanathan S. Workshop to address gaps in regulation of minimally manipulated autologous cell therapies for autologous use in Canada. Cytotherapy 19(12), 1400-1411 (2017).

-• Addresses a problematic 'gap' in Canada's regulation of minimally manipulated autologous cell products.

28. Ogbogu U, Du J, Koukio Y. The involvement of Canadian physicians in promoting and providing unproven and unapproved stem cell interventions. BMC Med. Ethics 19, 32 (2018).

-• Provides an informative and insightful empirical analysis of Canadian doctors selling and administering unproven stem cell interventions.

29. Blackwell T. Canadian clinics begin offering stem-cell treatments experts call unproven, possibly unsafe. National Post July 3, 2017. http://nationalpost.com/news/canada/canadian-clinics-begin-offering-stem-cell-treatments-experts-call-unproven-possibly-unsafe

30. Crowe Kelly. Unapproved stem cell therapies on the market in Canada. CBC News November 16, 2017. http://www.cbc.ca/news/health/stem-cell-private-clinic-health-canada-osteoarthritis-1.4401391

31. CBC News. Health Canada investigates Canadian stem cell clinics. CBC News. September 9, 2017. http://www.cbc.ca/news/health/second-opinion170909-1.4281703

32. Somberger J. People paying thousands of dollars for stem cell knee treatment. But does it work? Canadian Stem Cell Foundation. February 29, 2016. http://stemcellfoundation.ca/en/2016/02/29/people-paying-thousands-of-dollars-for-stem-cell-knee-treatment-but-does-it-work/

33. Crowe K. Controversial US stem cell clinics have Canadian connections. CBC Second Opinion. May 12, 2018. http://www.cbc.ca/news/health/second-opinion180511-1.4659092.

34. Lysaght T, Campbell A. Regulating autologous adult stem cells: the FDA steps up. Cell Stem Cell 9(5), 393-396 (2011).

35. Sipp D. Direct-to-consumer stem cell marketing and regulatory responses. Stem Cells Transl. Med. 2(9), 638-640 (2013).

36. Turner L. US stem cell clinics, patient safety, and the FDA. Trends Mol. Med. 21(5), 271-273 (2015).

37. Cyranoski D. FDA challenges stem-cell clinic. Nature 466, 909 (2010).

38. Cyranoski D. FDA's claims over stem cells upheld. Nature 488, 14 (2012).

39. Sipp D, McCabe C, Rasko J. Show drugs work before selling them. Nature 543(7644), 174-175 (2017).

40. Ledford H. Boom in unproven cell therapies intensifies regulatory debate. Nature 537(7619), 148 (2016).

41. Marks PW, Witten CM, Califf RM. Clarifying stem-cell therapy's benefits and risks. N. Engl. J. Med. 376(11), 1007-1009 (2016).

42. Lysaght T, Kerridge I, Sipp D, Porter G, Capps B. Oversight for clinical uses of autologous adult stem cells: lessons from international regulations. Cell Stem Cell 13(6), 647-651 (2013).

43. Ridgway A. The regulation of cell therapy products in Canada. Biologicals 43(5), 406-409 (2015).

- Provides a helpful overview of how cell therapy products are regulated in Canada.

44. Von Tigerstrom B, Nguyen T, Knoppers B. Regulation of stem cell-based therapies in Canada: current issues and concerns. Stem Cell Rev. 8(3), 623-628 (2012).

45. Zarzeczny A, Clark M. Unproven stem-cell based interventions \& physicians' professional obligations; a qualitative study with medical regulatory authorities in Canada. BMC Medical Ethics 15, 75 (2014). 
-• Examines the role provincial medical regulatory authorities in Canada play in overseeing healthcare providers marketing and administering unproven stem cell-based interventions.

46. Berger I, Ahmad A, Bansal A, Kapoor T, Sipp D, Rasko JE. Global distribution of businesses marketing stem cell-based interventions. Cell Stem Cell 19(2), 158-162 (2016).

47. Turner L, Knoepfler P. Selling stem cells in the USA: assessing the direct-to-consumer industry. Cell Stem Cell 19(2), 154-157 (2016).

48. Turner L, Knoepfler P. Selling stem cells in the USA: assessing the direct-to-consumer industry. Cell Stem Cell 19(2), $154-157$ (2016).

49. Leung EH, Flynn HW Jr, Albini TA, Medina CA. Retinal detachment after subretinal stem cell transplantation. Ophthalmic Surg. Lasers Imaging Retina 47(6), 600-601 (2016).

50. McGinley L. Three women blinded by unapproved stem-cell 'treatment' at South Florida clinic. The Washington Post (2017). www.washingtonpost.com/news/to-your-health/wp/2017/03/15/three-women-blinded-by-unapproved-stem-cell-treatment-at-southflorida-clinic/?utm_term $=.4 \mathrm{da} 61851 \mathrm{dbf} 0$

51. Kuriyan A, Albini T, Townsend J et al. Vision loss after intravitreal injection of autologous 'stem cells' for AMD. N. Engl. J. Med. 376(11), 1047-1053 (2017).

- The authors of this study document how unproven and unlicensed stem cell interventions provided by a US-clinic resulted in serious injuries suffered by several women suffering from age-related macular degeneration.

52. Kuriyan A, Albini T, Flynn Jr. H. The growing 'Stem Cell Clinic' problem. Am. J. Ophthalmology 177, xix-xx (2017).

53. Sipp D, Caulfield T, Kaye J et al. Marketing of unproven stem cell-based interventions: a call to action. Science Transl. Med. 9(397), pii: eaag0426 (2017).

-. Identifies numerous techniques companies use in an effort to lend legitimacy to advertised stem cell interventions.

54. CBC News. Health Canada investigates Canadian stem cell clinics. CBC News September 9, 2017. www.cbc.ca/news/health/second-opinion170909-1.4281703

55. Chisholm J, Von Tigerstrom B, Bedford P, Fradette J, Viswanathan S. Workshop to address gaps in regulation of minimally manipulated autologous cell therapies for autologous use in Canada. Cytotherapy 19(12), 1400-1411 (2017).

56. Rong A, Lam B, Ansari Z, Albini T. Vision loss secondary to autologous adipose stem cell injections: a rising problem. JAMA Ophthal. 136(1), 97-99 (2018).

57. Boudreault K, Justus S, Lee W, Mahajan V, Tsang S. Complications of autologous stem cell transplantation in retinitis pigmentosa. JAMA Ophthal. 134(6), 711-712 (2016).

58. Horner C, Tenenbaum E, Sipp D, Master Z. Can civil lawsuits stem the tide of direct-to-consumer marketing of unproven stem cell interventions. NPJ Regen. Med. 3, 5 (2018).

59. Martinho A, Turner L. Stem cells in court: historical trends in US legal cases related to stem cells. Regen. Med. 12(4), 419-430 (2017).

60. Freeman L. Court upholds license revocation of Bonita Springs doctor Zannos Grekos. Naples Daily News January 16, 2015. http://archive.naplesnews.com/news/health/court-upholds-license-revocation-of-bonita-springs-doctor-zannos-grekos-ep-876165328339821642.html/

61. Kemp P. The stem cell hard cell. BBC March 20, 2017. www.bbc.co.uk/programmes/p04w86gz

62. Saraf S, Cunningham M, Kuriyan A et al. Bilateral retinal detachments after intravitreal injection of adipose-derived 'stem cells' in a patient with exudative macular degeneration. Ophthalmic Surg. Lasers Imaging Retina 48(9), 772-775 (2017).

63. Marrero T. Unsatisfied former patient files class-action lawsuit against Lung Institute. Tampa Bay Times August 25, 2016. www.tampabay.com/news/courts/civil/unsatisfied-former-patient-files-class-action-lawsuit-against-lung/2290989

64. Wagner D. Amid Lawsuit, San Diego stem cell company pushes back on proposed regulations. KPBS (2016). www.kpbs.org/news/2016/dec/05/stemgenex-stem-cell-fda-class-action-lawsuit/

65. Arnold C. Texas stem cell rules may impede clinical research. Lancet 379(9828), 1776 (2012).

66. FDA. Statement from FDA Commissioner Scott Gottlieb, M.D. on the FDA's new policy steps and enforcement efforts to ensure proper oversight of stem cell therapies and regenerative medicine (2017).

www.fda.gov/NewsEvents/Newsroom/PressAnnouncements/ucm573443.htm 